DOI: $\underline{10.20472 / S S .2020 .9 .1 .004}$

\title{
UNLAWFULNESS AND COUNTERTYPES AS A \\ CIRCUMSTANCES PREVENTING ITS ATTRIBUTION WITHIN THE STRUCTURE OF CRIME - BASED ON THE EXAMPLE OF POLISH CRIMINAL LAW
}

\section{MICHAt GRUDECKI}

\begin{abstract}
:
This article is an attempt to collectively characterize one of the two types of circumstances precluding attribution of unlawfulness to the perpetrator's behavior, thus exempting him from criminal liability. The author presents circumstances (referred to as countertypes) which, by way of exception, exempt certain behaviors from criminal law prohibitions. These considerations are based on the model of crime adopted by the Author, derived from the concept of conjugate norms, widely accepted among Polish criminal lawyers. At the outset, the author points to a universal nature of criminal unlawfulness, which allows him to conduct investigations based on the selected model of bearing criminal liability.
\end{abstract}

\section{Keywords:}

criminal law, model of crime, justifications, defenses

JEL Classification: K14, K40, K49

\section{Authors:}

MICHAŁ GRUDECKI, University of Silesia in Katowice, Poland, Email: michalgrudecki@gmail.com

\section{Citation:}

MICHAŁ GRUDECKI (2020). Unlawfulness and countertypes as a circumstances preventing its attribution within the structure of crime - based on the example of Polish criminal law. International Journal of Social Sciences, Vol. IX(1), pp. 57-71., 10.20472/SS.2020.9.1.004 


\section{Universal nature of criminal unlawfulness and its independence of the adopted model of criminal liability - introduction*}

Despite the existence of different cultures and legal systems, both in specific parts of the world and in specific countries, relations in the reality are the same. A crime committed by a person in all countries of the world will constitute the same undesirable act occurring in the real world, regardless of its perception from the perspective of legal dogmatics. Also the purpose of criminal law, as a branch of law using implements that interfere most strongly with the rights and freedoms of individuals, is identical regardless of the country. The purpose of criminal law is to protect values that are key to the society and its proper functioning against behaviors violating them in a socially unacceptable way (Waszczyński, 1992: 10; Perkins and Boyce, 1982: 5).

This article is an attempt to collectively characterize one of the two types of circumstances that prevent attribution of unlawfulness to the perpetrator's behavior, thus exempting him from criminal liability. The thesis put forward in the introduction is that lawfulness is multi-faceted, which follows from a different nature of the two types of circumstances precluding attribution of unlawfulness to the perpetrator's act. One of them affects the social acceptability of behaviors, corrects the rules of dealing with a legal interest (primary legality), whereas the second, by way of exception, exempts certain behaviors from criminal law prohibitions (secondary legality countertypes). Although they have a common feature, that is social profitability of certain behaviors violating or endangering a legal interest, for axiological and criminalization reasons, they cannot be identified. Because of the scope of this article, it will be necessary to limit the considerations only to one type of such circumstances, namely countertypes.

I will conduct the investigation based on the chosen model of crime, built around the concept of conjugate norms, widely accepted among the Polish criminal lawyers. In order to prove usefulness of the analysis, in a further part of the introductory chapter, I will contrast the model of crime as used by criminal lawyers of the Germanic legal tradition, which also refers to Poland, with the model developed in common law countries. The presented similarities will enable continuation of the basic research based on the findings in the Polish legal order, since they prove that certain differences in the understanding of crime in individual countries do not preclude international scientific discourse at the level of structures involving unlawfulness of an act. It is hard to resist the impression that regardless of how the concept of crime is specifically understood in individual cultures and legal orders, criminal law analysis will always focus on two elements, the perpetrator and his act contrary to the legal order - including the question if any circumstances justifying either have occurred.

The views of Polish criminal lawyers on the responsibility for a crime are largely original although they are generally presumed to be inspired by chiefly German theoretical solutions (Tarapata, 2016: 148). Therefore, with certain modifications, the adopted crime structure includes three elements applying to each case: conformity of the perpetrator's act with the statutory description of the prohibited behavior, unlawfulness and culpability. In Polish criminal law, just like in the German context, circumstances excluding unlawfulness are clearly dissociated from circumstances excluding fault. Basically, the lack of criminality following from an impossibility to attribute unlawfulness to the perpetrator's act is connected with acceptance of or tolerance for his

\footnotetext{
* This article was written as a part of the research project funded by Polish National Science Center, decision number DEC-2018/29/N/HS5/00725.
} 
behavior in the society. On the other hand, the lack of fault is only an excuse for the perpetrator himself since in a given situation we cannot expect him to follow the legal norm (Bek, 2017: 265266). It is pointed out that the Anglo-American criminal law system differs from the Germanic one in that it does not use such clear demarcations in the construction of crime (Dubber, 2005: 1050). It focuses only on circumstances conditioning the crime (elements of an offense) or justify the crime (defenses). However, if you look closer, you may find certain similarities, especially in terms of exemption from criminal responsibility.

In Anglo-American criminal law, there are external elements (actus reus), relating to the perpetrator's act (such as consistence of the act with a crime definition), and the internal element (mens rea), involving his mental attitude, that condition a crime (Herring, 2009: 37; Molan and Bloy and Lanser 2003: 26). Among defenses, distinction is made between justification and excuse. Justifications exonerate the perpetrator's behavior because of special circumstances in which he acted, as a result of which his act can not be treated as unlawful (Molan and Bloy and Lanser, 2003: 349). Excuses, in turn, exempt the perpetrator from liability by protecting him from the attribution of fault (Molan and Bloy and Lanser, 2003: 349).

In light of the Anglo-American criminal law science, in order to prove innocence and avoid criminal responsibility, a defendant in criminal proceedings must prove an exonerating circumstance or non-existence of actus reus or mens rea (Molan, Bloy and Lanser, 2003: 349). Moreover, certain authors argue that courts treat unlawfulness as an element of actus reus, which is why the fact of acting under certain circumstances - for example in self-defense - exonerates the defender and negates the actus reus (Herring, 2009: 255). I will support exactly the same thesis based on the crime model adopted under the Polish legal order.

Summarizing this part of considerations, it must be emphasized that both in Polish criminal law, belonging to the German legal culture, and in the criminal law of common law countries the structure of crime is based on similar elements. The concept of actus reus corresponds to the construction of objective elements of an offense type, whereas mens rea is an equivalent of the subjective side. The disagreement as to the nature of justification - either as negating the actus reus or as a separate exonerating circumstance (pure defense) reminds the dispute over the nature of countertypes, waged between those who treat them as permissive circumstances and those who regard them as exonerating norms. Therefore, an analysis based on the Polish legal order and conclusions drawn from the normative structures and the criminal model adopted in the national criminal law system will be valuable for all lawyers and representatives of the judiciary regardless of the country in which they live.

\section{The concept of conjugate norms and the source of criminal law prohibitions}

Based on communis opinio of Polish criminal lawyers, provision of law is defined as a basic unit of legal text which has been separated graphically and has a specific meaning. Legal norms are interpreted from one, several or a whole group of provisions. They are utterances made by a competent public authority, specifying the prohibited or required course of action in given circumstances. Three types of legal norms, mutually related and known as conjugate norms, may be derived from criminal legislation, provisions of other legal branches or non-statutory sources. These are the sanctioned norm, the sanctioning norm and the competence norm.

The sanctioned norm is addressed to all citizens. It contains a prohibition of behavior undesirable in the society, or prescription of a required act. Its scope of application sets out the circumstances in which the prohibition or prescription must be followed and its subject. On the 
other hand, the addressee of the sanctioning norm are judicial authorities - mainly the court. The sanctioning norm contains an order to take sanctioning measures against persons violating the sanctioned norm, and its scope of application is identical with the scope of regulation of the sanctioned norm (the "coupling" point). A competence norm is connected with the sanctioning norm so that the scope of regulation of the sanctioning norm, and thus imposition of penalty by the court in accordance with the conventional procedure, delimits its scope of application, whose transgression instantiates the obligation to submit to the court decision (Kardas, 2012: 46).

The sanctioned norm governs the area of unlawfulness, which, in addition to fault and reprehensibility, is an element of crime. This relates to the question about the source of sanctioned norms, and especially whether such source can be provided by criminal law provisions.

Criminal law provisions may be a source of sanctioned norms governing criminal unlawfulness. As Dąbrowska-Kardas (2012: 173) points out, this thesis follows directly from two provisions of the Polish Criminal Code, defining the concepts of criminal liability (Article $1 \S 1$ ) and prohibited act (Article $115 \S 1$ ). According to them, only a person committing an act prohibited (behavior realizing the elements defined in a criminal statute) under a penalty by a statute in force at the time of its commission is subject to criminal liability. Considering that violation of the sanctioned norm is a precondition to criminal liability, it is difficult to accept the thesis that its sources can be found in non-criminal provisions (Wyrembak, 2007: 67, Dąbrowska-Kardas, 2012: 190).

Another argument for the above thesis is that location of the sources of sanctioned norms outside criminal law renders it impossible to find the prohibition, and thus attribute unlawfulness to behaviors at the pre-commission stage (preparation, attempt), forms of accessorial liability (incitement or assistance), exposure to danger or several other types (crime of homicide or incest). This approach has numerous supporters (Wyrembak, 2007; Królikowski, 2010; Kaczmarek, 1996) and legitimately shows that in criminal law there are many provisions prohibiting behaviors irrelevant to other legal branches (Kaczmarek, 1996: 134).

\section{The relations between elements of a prohibited act and conjugate norms}

By statutory description of a prohibited act - typification - the legislator formally distinguishes between socially dangerous behaviors which threaten legal interests and may constitute crimes and ones which are criminally irrelevant (Długosz, 2016: 333). Typification has a selective and guarantee function, defining the boundary between behaviors prohibited under penalty and permissible ones as well as those that are forbidden but not covered by a criminal sanctioning norm (Długosz, 2016: 338-339). The statutory elements of a prohibited act include the subject (potential perpetrator of the prohibited act), object of protection (legal interest protected by typification), the subjective side (psychological relation of the perpetrator to the realization of other elements) and the objective side (verbal mark along with the rules of dealing with a legal interest, indicating the prohibited behavior, modal circumstances concretizing the prohibited behavior, the object of commission - the object directly affected by the perpetrator and the effect - a change in the outside world resulting from the perpetrator's behavior or independent of such behavior).

In Polish criminal law, two positions are distinguished in reference to the above problem. According to the first one, all elements of a prohibited act belong to the sphere of unlawfulness, delimiting at the same time the sphere of penality. The scope of prohibited or prescribed 
behaviors coincides with the scope of behaviors prohibited under penalty (Kardas, 2018: 35). Only realization of all elements of an offense type by the perpetrator may point to unlawfulness of an act.

The second position distinguishes between elements of unlawfulness, whose realization entails violation of the sanctioned norm, and elements of penality, whose realization entails violation of the sanctioning norm (Jędrzejewski, 2016: 82). According to this view, the elements deciding about violation of the sanctioned norm, thus entailing unlawfulness of an act, may not include elements of the subjective side or of the objective side (modal circumstances, object of commission and effect) except for the rules of dealing with a legal interest (Jędrzejewski, 2016: 82). Materialization of these features is to decide only about the act's penality and not its unlawfulness. In this approach, unlawfulness is characterized only by objective elements, such as transgression of an objective prohibition or prescription to perform an act and endanger thereby a legal interest, regardless of any subjective elements or elements independent of the behavior (Kardas, 2018: 14- 15).

Recognition that all elements of a prohibited act are situated in the sanctioned norm is a natural consequence of the adopted position according to which the sources of sanctioned norms are criminal law provisions. I have assumed, pointing to the definitions of criminal liability and prohibited act, that all elements of a type, including the subjective and objective side and the element of effect delimit the scope of prohibition. According to the pluralistic conception of unlawfulness, accepted in this article, it should be noted that criminal law evaluation is independent of other assessments relating to and falling within the limits of its teleology (Jędrzejewski, 2016: 87). This means that the sanctioned norm may be violated only when the perpetrator's behavior realizes all subjective and objective elements of a type (Jędrzejewski, 2016: 87). As pointed out by Żółtek (2014: 418), the type of a prohibited act, as a model of prohibited behavior, forms the content of a sanctioned norm, with the proviso that the prohibited act type corresponds only to the scope of regulation of the sanctioned norm since it describes the prohibited or prescribed behavior.

\section{Criminalization as a method of creating the area of criminal unlawfulness}

There are various values in the society (social interests) that are appreciated by and desirable for the society members whose violation or exposure to danger is negatively evaluated (Zawłocki, 2007: 103, Tarapata, 2016: 105). The legislator wants to protect these positively assessed states and affords them protection by introducing a legal norm, transforming social interests into legal interests (Tarapata, 2016: 58). In this way, the legislator makes a certain evaluation, which in a democratic state of ruled by law should be based on the axiological system accepted by the society. If legal interests are not social interests, their protection by law will only limit the freedom of individuals, which may paralyze social life. If the legislator adheres to a different axiological system than the society, de facto decriminalization may take place and, consequently, a notorious lack of prosecution despite realization of elements of a given crime (Plebanek, 2009: 91). It may be assumed, as Plebanek (2009: 91) did, that the current axiological system in a given society is reflected in the Constitution. Of course, this assumption should be combined with the recognition that the system, as well as the Constitution itself, are based on value judgments actually functioning in a given community (Plebanek, 2009: 91). 
In some cases, criminal law, as a branch of law using the most severe means of response to violations of prohibitions or failures to comply with prescriptions, offers additional protection to certain legal interests (Patora, 2018: 83). This happens when the legislator introduces a criminal sanctioned norm prohibiting violation of such interests and a sanctioning norm attached to it, addressed to the judicial authorities, so that they punish the perpetrator violating the sanctioned norm. This process is called criminalization. Interests protected by criminal law are legal interests protected by sanctioned norms, the source of which are, inter alia, criminal law provisions, and therefore they may be called objects of individual protection.

The criminalization process consists in submitting certain behaviors to criminal law prohibitions, the violation of which may result in a penalty, with a view to protecting particularly valuable legal interests. Therefore, it is nothing else but limitation of freedom of an individual, which prevents him, to a certain degree, from approaching a given interest according to his own will. According to the norm under Art. 31(3) of the Constitution of the Republic of Poland, any limitation upon the exercise of constitutional freedoms and rights may be imposed only by statute, and only when necessary in a democratic state for the protection of its security or public order, or to protect the natural environment, health or public morals, or the freedoms and rights of other persons. Such limitations shall not violate the essence of freedoms and rights. This catalog, as Biłgorajski (2013: 223) points out, consists of terms which are general clauses, and in addition as Wojtyczek (1999: 41) argues - is so vague and imprecise that it permits protection of almost all constitutional values. The legislator must set the limits to the realization of freedom of an individual so that such freedom may also be exercised by others (Kulesza, 2017: 27). It must be concluded (Giezek, 2006: 73) that people are unwilling to compromise and it is difficult to maintain balance between conflicting social interests.

Out of the norm of Art. 31 para. 3 of the Constitution of the Republic of Poland, it is possible to infer three preconditions that must be met by any limitation of constitutional rights or freedoms through statutory regulation. In accordance with the principle of usefulness, introduction of a prohibition and subsequent criminal repression is only admissible if it constitutes an effective tool to combat the threats mentioned in Art. 31(3). The principle of necessity requires the legislator to consider whether there are any less severe tools to achieve the intended goal criminal law is ultima ratio of the legal system and its instruments may be used only when necessary. The principle of proportionality sensu stricto is a requirement to consider whether the limitation of liberty by introduction of a criminal sanctioned norm will not be less beneficial than establishment of stronger protection of a given legal interest (Kulesza, 2017: 225).

\section{Countertypification as a method of adjustment in the area of unlawfulness - the legal nature of countertypes}

By criminalization, the legislator for the first time resolves the conflict of at least two interests one being an individual's freedom to deal with the legal interests (broadly understood freedom of approaching such interest or interests) whose protection is to be covered by a given type of prohibited act. Synthetic formulation of a type of prohibited act results in criminal prohibition of all factual circumstances violating a legal interest, including those which, for certain reasons, should not be covered in a given repetitive situation (Majewski, 2017: 403). It may happen that in certain simultaneous circumstances legal interests do not receive the same legal protection (Zontek, 2017: 117) - there is a need to resolve the resulting conflict anew. By way of criminalization, the legislator is not able to fully optimally resolve conflicts of legal interests (Plebanek, 2006: 71). 
Therefore, the legislator may delegate the possibility of resolving such conflicts to courts, by creating a provision containing a countertype as a specific adjustment of the criminalization decision in more specifically defined situations. In a countertype situation, behaviors violating one interest to protect another will not be unlawful. The basis for limiting the criminal law protection of one of the interests may be the need to fulfill an obligation under another norm or right. In the remainder of this chapter, I will present the legal nature of countertypes and move on to their essence and characteristics.

As Bielski indicates (2010: 29-30), in the light of the abovementioned concept of conjugate norms, on which the crime model is based, there are two possibilities of locating countertypes the first one views countertypes as circumstances analyzed within the scope of application or regulation of the sanctioned norm (sphere of unlawfulness), whereas the second reduces them to circumstances restricting the scope of application of the sanctioning norm (sphere of penality). Within those models, five concepts accounting for their legal nature can be distinguished.

According to the first view, countertypes were located within the scope of regulation of the sanctioned norm, which viewed their negation as elements of a type of prohibited act. According to this theory, the appearance of countertypes in a given situation eliminates the unlawfulness of behavior, because they preclude the realization of elements of a prohibited act. They are, therefore, circumstances that cannot exist if one is to speak of an unlawful act (Opar, 2006: 8). This concept has been criticized because of an internal contradiction resulting from the fact that countertypes have their own set of elements, which, in addition, through their connection with the type, requires realization of that type's elements (Zoll, 1975: 84). If, under this theory, it is assumed that the phrase "to kill a man" is to be understood as "to kill a human otherwise than in a necessary defense," the perpetrator taking life within the framework of that countertype "kills a human otherwise than in necessary defense but in necessary defense" (Patryas, 1988: 29). Recognition of a behavior in a countertype situation as non-realizing the essence of an act (elements of the type) has also been criticized (Jędrzejewski, 2005: 191, Marek and Satko, 2010: 14, Kaczmarek, 2008: 22). An additional equally serious drawback signaled by certain authors is the perpetrator's need to take into account the absence of circumstances excluding unlawfulness (negative features) so that the perpetrator may be attributed with intent (Jędrzejewski, 2005: 191, Opar, 2006: 13). This drawback, however, seems to be only ostensible because it seems rather natural that a person should be aware that he is not in extraordinary circumstances when violating a prohibition or prescription under a sanctioned norm, as proponents of the discussed theory point out ( Wolter, 1983: 93; Giezek, 2009: 141).

The second concept, of which Zoll (1982: 122) is the best known advocate, was that countertypes are an example of statements permitting transgression of the sanctioned norm. According to Zoll (2009: 110; 2010: 358), countertypes are a separate, independent element of the legal order, constituting a kind of conflict rule which justifies violation by the perpetrator. This is the so-called secondary legality - a behavior violating the sanctioned norm is lawful under the "legalizing" function of countertypes (Zoll, 2010: 358). Countertypes, although including their own set of elements, additionally comprise the type's elements because they make sense only in connection with such type (Zoll, 1982: 128-129). Zoll's concept is subject to rather strong criticism due to the lack of acceptance in legal science of the possibility to discern permissive norms (Bielski, 2010: 34, Majewski, 2013: 69). Its adversaries indicate that a permissive norm cannot be treated as an opposite to the sanctioned norm but as a narrowing of the scope of application of such norm (Bielski, 2010: 34, Majewski, 2013: 61). In addition, they claim that its assumptions contradict the paradigm of the rational legislator who cannot tolerate simultaneous validity of two 
norms - prohibiting and permitting a given behavior (Bielski, 2010: 35, Majewski, 2017: 409-410). A legal system with conflicting norms would be unable to govern human behavior, ineffective and irrational, and the law created in such legislative framework - wicked and immoral (Majewski, 2017: 412).

Bearing in mind the flaws of the above theories, some authors attempted to prove that countertypes are located within the sanctioning norm. For example, Bielski (2010: 44) claims that behavior undertaken in a countertype situation violates the prohibition of the sanctioned norm but is excluded from the scope of application of the conjugate sanctioning norm because of the need for its exoneration. Countertype behavior violates the sanctioned norm, and the "exempting" countertype function activates only under the sanctioning norm (Bielski, 2010: 45). In this way, the author avoids the criticism of internal contradiction in the legal order. This concept, according to Bielski (2010: 41, 47), allows to distinguish between countertype and primarily legal behaviors (violation of the sanctioned norm, from the point of view of its purpose, is identical with a noncountertype situation), which is not possible under alternative theories. It corresponds to the monistic view of unlawfulness and allows to explain, within such framework, a different scope of the necessity countertype in criminal and civil law, and to justify the need to distinguish the subjective element in countertypes, assuming that such element does not belong to the sphere of unlawfulness (Bielski, 2010: 48 -49). In addition, Bielski (2010: 49) points out that criminal law provisions defining countertypes exclude criminal liability, and not unlawfulness.

Countertypes are also treated as clauses preventing realization of the sanctioning norm by Pohl (2007: 200). This author justifies his view with the theory of strong authorization relating to acts which are both regulated and non-prohibited, which, in his opinion, suits the construction of countertypes as institutions inseparably connected with types. He claims that the construction of countertype implies the perpetrator's necessity to transgress the sanctioned norm but opposes the treatment of countertypes as independent permissive norms, invoking the discussed opinion on the inadmissibility of their construction (Pohl, 2007: 200).

Before deploying arguments against the above conception, I will discuss another, very similar one, against which analogous objections can be made. Dudek and Małecki (2019) approve the criticism of permissive norms and move the considerations on the legal nature of countertypes to the level of the sanctioning norm and the conjugated competency norm. In their opinion, a provision of law establishing a countertype has a dual character - it is a pattern for evaluation of a given behavior within the structure of crime and it contains a conflict clause, which allows to settle criminal law consequences of single-act concurrence between the type and the countertype (Dudek and Małecki, 2019: 48). According to Dudek and Małecki (2019: 49), the countertype provision fully defines the criminally relevant aspect of reality and does not need to be interpreted in conjunction with the provision defining statutory elements of a prohibited act. The authors argue against the conclusion that a countertype is meaningless without a type. Upon realization of countertype elements, according to the discussed theory, the competence of the appropriate authority to criminally evaluate an act under the typifying provision is cancelled - the act can be evaluated only under the legal provision containing the countertype (Dudek and Małecki, 2019: 48). Proponents of the described theory argue that due to elimination of the typifying provision, from the point of view of criminal law attribution, transgression of the sanctioned norm will not be reflected on the procedural level, and the relevant authorities may not ascertain or establish unlawfulness of an act (Dudek and Małecki, 2019: 57). 
Opting for the concept of Bielski, Pohl or the discussed new attempt by Dudek and Małecki at grasping the legal nature of countertypes necessitates the acceptance of discrepancies between the scope of regulation of the sanctioned norm and the scope of application of the sanctioning norm (Giezek, 2009: 152). According to this concept, since a countertype materializes only under the sanctioning norm and the conjugated competency norm, a behavior falling within its framework would violate the sanctioned norm and, therefore, be unlawful - prohibited, which would lead to a paradox implying, for example, prohibition of necessary defense, which under the Polish law is permissible only against an unlawful attack (Giezek, 2009: 152, Tarapata, 2016: 355). Eventually, since there are no exceptions on the level of the sanctioned norm, the prohibition to cause detriment to the legal interests of the assailant in a socially unacceptable manner (contrary to rules of caution) is absolute. In addition, de lege lata, this theory raises yet another problem relating to necessary defense. Assuming that a behavior undertaken in a countertype situation is not legal, it is necessary to accept the thesis about the admissibility of necessary defense against such behavior - since the attack is unlawful (Tarapata, 2016: 355). The adoption of this theory definitely undermines the significance and effectiveness of countertype in criminal law.

It is impossible to reject the objections against the other theories presented above. Adoption of the understanding of countertypes as circumstances modifying the scope of regulation of the sanctioned norm compels non-intuitive rendition of the verbal elements defining the prohibition in the sanctioned norm, which leads to their detachment from the events taking place in reality (Zoll, 1982: 101). For example, a behavior undertaken in necessary defense, which in the eyes of the society clearly amounts to homicide, would not fulfil of the verbal element "kills" under Art. $148 \S 1$ of the Criminal Code. On the other hand, one may not accept the theory treating countertypes as exonerating norms because of the resulting contradiction within the legal system. In my opinion, locating the countertype as a circumstance limiting the scope of application of the sanctioned norm suits its nature best. This solution is also supported by representatives of criminal law science (Patryas, 1988: 30, Kaczmarek, 2008: 27, Tarapata, 2016: 365). I opt for approaching the opposites of countertypes as components co-determining the addressee's situation (characteristics of that situation) in which a given sanctioned norm is applicable. The lack of a countertype allows in a given situation to actuate the scope of application of such norm. A contrario, under this conception, acting in a countertype situation renders the norm simply inapplicable, and therefore its violation (of the prohibition) is impossible. The perpetrator acting within the countertype framework fulfils with his behavior the elements of a prohibited act and, thus, violates the scope of regulation of the sanctioned norm prohibiting such behavior. At the same time, he fulfils the elements of a countertype, activating the provision resulting in the limitation in scope of the application of that norm, which lifts, under strictly prescribed conditions, the binding force of the prohibition in relation to the perpetrator in a specific factual situation. It was alleged against the advocated concept - as against the negative features theory in which countertype negations activated the scope of regulation of the sanctioned norm - that the legal interest violated by the person in a countertype situation (conflict of interests) loses such status and ceases to be protected (Dębski, 2012: 277, Banaszczyk, 2017: 209). To quote the legendary example, cited as well by Dudek and Małecki (2019: 58-59), it was pointed out that the conception also equates murder of a human in necessary defense with killing a mosquito since it nullifies - for example in case of necessary defense - the status of legal interest with regard to the assailant's interests, such as his life or health. In response to these allegations, it must be emphasized that, in a countertype situation, there is still a violation or exposure to 
danger of an interest protected by criminal law, because an interest given such attribute cannot forfeit it otherwise than by decriminalization. However, the legislator may provide that, in specific repetitive situations, a damage or even destruction of a legal interest is not an act prohibited by a criminal sanctioned norm.

\section{Preconditions to countertypification and elements of countertypes}

Knowing the legal nature of countertypes, one should answer the question in what situations the legislator permits violation or exposure to the danger of a legal interest. Common attributes of all countertypes may be decoded by analyzing their elements. Countertypes, just like types, have their own determinacy. Therefore, they specify circumstances, expressed in a descriptive language, under which a given prohibition will not be binding. Based on the analysis of countertypes in criminal law, the following countertype elements may be hypothetically distinguished, which in a countertype situation should be interpreted in conjunction with the elements of a type:

1) indication of the circumstances in which a conflict of legal interests may take place;

2) partial indication of the colliding legal interests;

3 ) indication of a viable method of resolving the conflict of legal interests (behavior of the person in a countertype situation);

4) indication of the psychological attitude with which the person acting in a countertype situation is to solve the conflict.

An undeniable feature of all countertype situations is the action of the perpetrator who infringes a legal interest protected by law in order to protect another interest with the same attribute. Zoll's thesis $(1982: 104,108)$ seems to be legitimate that protection of a legal interest may consist not only in its preservation in the current condition but also in its multiplication or obtaining a new interest. Only in such situations an infringement or exposure of a legal interest to danger or non-compliance with the rules of dealing with it may be considered legal. This view is confirmed by the principle of proportionality (Art. 31(3) of the Constitution of the Republic of Poland). In the words of Plebanek (2009: 108), that principle imposes the requirement to maintain a proper proportion between the legal interests violated by an intervention and the legal interests protected by the same intervention. Violation of an interest may be permitted only if necessary for the realization of another legal interest.

Countertype is an adjustment of the legislator's decision to criminalize made after the proportionality test, which allows to maintain the said proportion and demonstrates how to prioritize in case of a conflict of goods. Such circumstance restricts the right of one person to benefit from the protection of his legal interests as afforded by criminal law and, at the same time, increases the freedom of conduct of another person acting in a countertype situation. This statement implies the legislator's need to apply the proportionality test under Art. 31(3) of the Constitution of the Republic of Poland when making decisions about countertypification, and especially when defining the countertype elements, just as in the typification process. The legislator must therefore examine if a limitation of the criminal law protection of one of the legal interests in order to resolve a conflict with another is useful, necessary and if it does not nullify the essence of that protection. 
Limitation of the scope of application of the sanctioned norm by way of a countertype may therefore take place only in case of a conflict of at least two non-identical (or identical but not held by the same entity) legal interests protected by criminal law which makes a repetitive but usually exceptional situation (Rajzman, 1966: 45, Majewski, 2013: 21, Plebanek, 2006: 86). In case of such conflict, all legal interests cannot be preserved and, therefore, one must be compromised to protect others (Sitarz and Bek and Hanc, 2017: 69). The judicial authority must resolve the conflict between two sanctioned norms, protecting each of the colliding interests, using the instructions given by the legislator in the form of countertype elements. In such situations, countertype is a tool allowing to "disable" one of the norms by limiting the scope of its application and thus to resolve a contradiction which may not subsist in the legal system.

It should also be noted that since a type is a description of behavior which is constantly present in society, also a countertype may apply only to repeatable conflicts of interests. As in the case of type, which has generalizing features, discerning a certain aspect of human acting or omission from an entire spectrum of behaviors, also a countertype generalizes but in the opposite direction (Wolter, 1963: 504).

By creating a countertype, the legislator resolves a collision of interests at the legislative level, taking into account the balance of gains and losses, and considering the axiology and functions of the legal system (Filar, 2007: 52; Plebanek, 2006: 86-87). When correcting the decision to criminalize, and thus modifying the level of criminal law protection of interests, the legislator must be guided by the same premises as in the introduction of a sanctioned norm into the system. Therefore, when creating a countertype, it is required, as mentioned above, to resort to the principle of proportionality and, in particular, to ascertain the social profitability of such adjustment. The catalogue of legal interests whose compromising is socially profitable in typical situations is determined by the legislator, when creating a given countertype. In doing so, the legislator should consider the values appreciated in the society, the level of acceptance of a danger to legal interests, development in the fields of science, technology, medicine, culture, social changes and moods, and expectations of the members of such group.

It is assumed in the literature that violation of one legal interest in a countertype situation is socially tolerated due to the favorable balance of gains and losses resulting from such sacrifice (social profitability), which neutralizes the negative assessment of the behavior of the violating person or the effect of such behavior in a countertype situation (Zoll, 1982: 103, 110). It seems, however, that quite the opposite is the case. The characteristic feature of countertypes is not social profitability or necessity to sacrifice one legal interest but social unprofitability of the lack of such sacrifice. From the point of view of the society, it will be unfavorable if both colliding legal interests are damaged when the conflict cannot be lawfully settled. Arguments for such thesis can be found in the literature. Zoll points out (2005: 111) that countertypes are profitable because in their absence social harm would be even greater. At another place, he writes that violation of a legal interest in a countertype situation is the lesser evil (Zoll, 1977: 53). Banaszczyk is of a similar opinion (2017: 210), indicating that, due to the nature of countertype situations, it would be unfair to consider unlawful a behavior undertaken within their framework. It seems, therefore, that the tolerance for countertype behaviors is justified not as much by social profitability as by the necessity to consider certain acts legal despite their negative assessment following from infringements of legal interests. In case of an insoluble conflict of legal interests, it is simply necessary to compromise one, and both the society and, most importantly, the legislator must accept that. At this point, the principle of solidarity, as described in German science, may be invoked, according to which members of the society agree to protect one legal interest at the 
expense of lesser protection to another because in future they may benefit from such compromise in a similar situation (Zimmermann, 2014: 272-273). The said necessity may result from actual impossibility to solve a conflict of interests otherwise than by sacrificing one of them (for example, the countertypes of necessity or ultimate need), from social profitability of such solution (for example, the countertypes of innovative experiment or lawful criticism) or equity (for example, the countertypes of necessary defense or citizen's arrest).

In this article, I accepted that despite the precedence of objective elements in the assessment of the social harmfulness of a behavior, negative assessment of an act depends on the occurrence of the subjective element of intent. In this regard, many authors claim that the same must apply, but a contrario - through the prism of social profitability - to countertypes, and therefore only such behavior of the perpetrator which is undertaken with the intention to rescue one of the colliding interests may be considered profitable. Justification for the belief in the subjective element of countertypes must be sought in their essence, or more precisely - in the exceptional nature of the authorization narrowing the scope of the sanctioned norm (Wąsek, 1988: 62). Realization of the elements of a countertype triggers a violation or exposure of a social interest to unacceptable danger, and is, therefore, socially harmful. The perpetrator's awareness of acting in a countertype situation and, consequently, of a conflict of legal interests requiring sacrifice of one interest affects the assessment of social tolerability of his behavior. The society accepts his harmful conduct since it is caused by the need to resolve the conflict. Unaware acting in a countertype situation, even though the perpetrator's behavior would also be required and sometimes even profitable, may not be tolerated because of his intention to commit a prohibited act. One should not accept behaviors violating legal interests which are inspired by ill will, whose perpetrator only accidentally realizes the objective elements of a countertype, but which would otherwise render the act lawful (Daniluk, 2005: 44).

\section{Summary}

Various human behaviors, although seemingly realizing the verbal element of a prohibited act definition, may be devoid of unlawfulness, and, therefore, not considered crimes. This may follow from secondary legalization by a countertype. The criteria indicating that we have to do with such situation are as follows:

1) a behavior, belonging to the category of general and repetitive behaviors, infringes a legal interest (violates or endangers such interest as a result of violation of rules relating to it) but:

a) is socially profitable as the "lesser evil" in approaching the legal interest, although unacceptable, arousing anxiety or condemnation; and

b) is intentionally undertaken to resolve a conflict of different, concrete, decodable, and at least two non-identical (or identical, but not held by the same person) legal interests protected by criminal law; and

c) sacrifices one legal interest and constitutes a choice of the prevailing benefit consistent with social interests, with the intention to protect another interest. 


\section{References}

Banaszczyk, Z. (2017). W sprawie uznania klauzuli sumienia lekarza za okoliczność wyłączającą bezprawność oraz cywilnoprawnych implikacji takiej kwalifikacji. In Robaczyński W (ed) Czynić postęp w prawie. Księga jubileuszowa dedykowana Profesor Birucie Lewaszkiewicz-Petrykowskiej (205-239). Łódź. Wydawnictwo Uniwersytetu Łódzkiego.

Bek, D. (2017). Obrona przez kulturę. Analiza na gruncie polskiego prawa karnego. Warszawa: Wydawnictwo C. H. Beck.

Bielski, M. (2010). Koncepcja kontratypów jako okoliczności wyłączających karalność. Czasopismo Prawa Karnego i Nauk Penalnych 14 (2), 25-50.

Biłgorajski, A. (2013). Granice wolności wypowiedzi: studium konstytucyjne. Warszawa: Wydawnictwo Sejmowe.

Daniluk, P. (2005). Warunki determinujące skuteczność zgody uprawnionego w prawie karnym. Palestra 12,34-44.

Dąbrowska-Kardas, M. (2012). Analiza dyrektywalna przepisów części ogólnej Kodeksu karnego. Warszawa: LEX Wolters Kluwer business.

Dębski, R. (2012). Jeszcze o normie prawnokarnej. In Adamski, A. et al. (Eds.) Nauki penalne wobec szybkich przemian socjokulturowych. Księga jubileuszowa Profesora Mariana Filara. T. 1 (109-129). Toruń: Wydawnictwo Adam Marszałek.

Długosz, J. (2016). Ustawowa wyłączność i określoność w prawie karnym. Warszawa: Wydawnictwo C. H. Beck.

Dubber, M.D. (2005). The Promise of German Criminal Law: A Science of Crime and Punishment. German Law Journal 6, 1049-1071. https://doi.org/10.1017/S2071832200014127

Dudek, P.M. \& Małecki, M. (2019). Charakter prawny kontratypu w świetle koncepcji zbiegu wartościowań tego samego czynu. Państwo i Prawo 877 (3), 45-61.

Herring, J. (2009). Criminal Law. Basingstoke, New York: Palgrave Macmillan.

Filar, M. (2007). W obronie obrony koniecznej. In Krajewski, K. (Ed.) Nauki penalne wobec problemów współczesnej przestępczości. Księga jubileuszowa z okazji 70. rocznicy urodzin Profesora Andrzeja Gaberle (51-59). Warszawa, Kraków: Oficyna Wolters Kluwer business.

Giezek, J. (2006). Kolizja dóbr a prawnokarna ochrona wolności. In Mozgawa, M. (Ed.) Prawnokarne aspekty wolności (71-88). Kraków: Wolters Kluwer - Kantor Wydawniczy "Zakamycze".

Giezek, J. (2009). „Zezwolenie” na naruszenie dobra prawnego - negatywne znamię typu czy okoliczność kontratypowa. In Pohl, Ł. (Ed.) Aktualne problemy prawa karnego. Księga pamiątkowa z okazji Jubileuszu 70. urodzin Profesora Andrzeja J. Szwarca (131-154). Poznań: Wydawnictwo Naukowe Uniwersytetu im. Adama Mickiewicza.

Jędrzejewski, Z. (2005). Urojenie znamienia kontratypu a problem struktury przestępstwa. In Gardocki, L. et al. (Eds.) Gaudium in litteris est. Księga jubileuszowa ofiarowana Pani Profesor Genowefie Rejman z okazji osiemdziesiątych urodzin (131-154). Warszawa: Liber.

Jędrzejewski, Z. (2016). Typ czynu zabronionego a struktura normy. In Bieńkowska, B. \& Jędrzejewski, Z. (Eds.) Problemy współczesnego prawa karnego. Część pierwsza (77-87). Warszawa: Wydawnictwo C. H. Beck.

Kaczmarek, T. (1996). Recenzja. Ryszard Dębski: Pozaustawowe znamiona przestępstwa (O ustawowym charakterze norm prawa karnego i znamionach typu czynu zabronionego nie określonych w ustawie). Państwo i Prawo 606-607 (8-9), 132-137. 
Kaczmarek, T. (2008). O tzw. okolicznościach „wyłączających” bezprawność czynu. Państwo i Prawo 752 (10), 21-33.

Kardas. P. (2012). O relacjach między strukturą przestępstwa a dekodowanymi z przepisów prawa karnego strukturami normatywnymi. Czasopismo Prawa Karnego i Nauk Penalnych 16 (4), 5-63.

Kardas. P. (2018). Subiektywne komponenty czynu a bezprawność i okoliczności ją wyłączające. Kilka uwag o przyjmowanych w piśmiennictwie karnistycznym płaszczyznach i metodach analizy subiektywnych elementów bezprawności. Acta luris Stetinensis 21(1), 7-43. DOI: 10.18276/ais.2018.21-01

Królikowski, M. (2010). Okoliczności wyłączające bezprawność jako konstrukcja sprawiedliwości korygującej. Czasopismo Prawa Karnego i Nauk Penalnych 14 (2), 5-24.

Kulesza, J. (2017). Problemy teorii kryminalizacji. Studium z zakresu prawa karnego i konstytucyjnego. Łódź: Wydawnictwo Uniwersytetu Łódzkiego.

Majewski, J. (2013). Okoliczności wyłączające bezprawność a znamiona subiektywne. Warszawa: Lex a Wolters Kluwer business.

Majewski, J. (2017). Czy idea tak zwanej wtórnej legalności się broni. Nowa Kodyfikacja Prawa Karnego 43, 401-420.

Marek, A. \& Satko, J. (2000). Okoliczności wyłączające bezprawność czynu : komentarze, piśmiennictwo, orzecznictwo. Warszawa: Ministerstwo Sprawiedliwości.

Molan, M., Bloy. D. \& Lanser, D. (2003). Modern Criminal Law. London, Sydney, Portland, Oregon: Cavendish.

Opar, A. (2006). Filozoficzno-metodologiczne aspekty teorii negatywnych znamion czynu przestępnego. Czasopismo Prawa Karnego i Nauk Penalnych 10 (2), 5-24.

Patora, K. (2018). Pojęcie „bezprawności” w różnych dziedzinach prawa. Prokuratura i Prawo 10, 64-93.

Patryas, W. (1988). Interpretacja karnistyczna: studium metodologiczne. Poznań: Wydawnictwo Naukowe UAM.

Perkins, R. \& Boyce, R. (1982). Criminal Law. Mineola, New York: The Foundation Press, Inc.

Plebanek, E. (2006). O obronie koniecznej i innych kontratypach w świetle zasady proporcjonalności. Czasopismo Prawa Karnego i Nauk Penalnych 10 (1), 71-94.

Plebanek, E. (2009). Materialne określenie przestępstwa. Warszawa: Oficyna a Wolters Kluwer business.

Pohl, Ł. (2007). Struktura normy sankcjonowanej w prawie karnym: zagadnienia ogólne. Poznań: Wydawnictwo Naukowe Uniwersytetu im. Adama Mickiewicza.

Rajzman, H. (1966). Analogia in bonam partem i zasada legalizmu w prawie karnym. Annales Universitatis Mariae Curie-Skłodowska. Sectio G. Ius. 13, 41-71.

Sitarz, O., Bek D. \& Hanc, J. (2017). Wpływ klauzuli sumienia i obrony przez kulturę na ocenę elementów struktury przestępstwa. Archiwum Filozofii Prawa i Filozofii Społecznej 15 (2), 60-79.

Tarapata, S. (2016). Dobro prawne w strukturze przestępstwa: analiza teoretyczna i dogmatyczna. Warszawa: Wolters Kluwer.

Warylewski, J. (2008). Zasada ustawowej określoności przesłanek odpowiedzialności karnej a kontratypy pozaustawowe. In Majewski, J. (Ed.) Okoliczności wyłączające bezprawność czynu. Materiały IV Bielańskiego Kolokwium Karnistycznego (21-38). Toruń: Towarzystwo Naukowe Organizacji i Kierownictwa "Dom Organizatora".

Waszczyński, J. (1992). In Waszczyński, J. (Ed.) Prawo karne w zarysie. Nauka o ustawie karnej $i$ przestępstwie (7-22). Łódź: Wydawnictwo Uniwersytetu Łódzkiego. 
Wąsek, A. (1988). Problematyka kontratypów przy przestępstwach nieumyślnych. Palestra 10, 61-71.

Wojtyczek, K. (1999). Zasada proporcjonalności jako granica prawa karania. Czasopismo Prawa Karnego i Nauk Penalnych 3 (2), 33-51.

Wolter, W. (1963). O kontratypach i społecznej szkodliwości czynu. Państwo i Prawo 212 (10), 502-511.

Wolter, W. (1983). Wokół problematyki błędu w prawie karnym. Państwo i Prawo 445 (3), 90-95.

Wyrembak, J. (2007). Bezprawność jako sprzeczność czynu sprawcy z normą prawną. Wojskowy Przegląd Prawniczy 243 (3), 60-69.

Zawłocki, R. (2007). Pojęcie i funkcje społecznej szkodliwości czynu w prawie karnym. Warszawa: Wydawnictwo C. H. Beck.

Zimmermann, T. (2014). Justification or Excuse? The Collision of Positive Duties in German Criminal Law. The Journal of Criminal Law 78, 263-276. https://doi.org/10.1350/jcla.2014.78.3.922

Zoll, A. (1975). Stosunek kontratypów do ustawowej określoności czynu. Państwo i Prawo 350 (4), 83-92.

Zoll, A. (1977). Z problematyki kontratypów. Zeszyty Naukowe Uniwersytetu Jagiellońskiego. Prace Prawnicze 74, 49-78.

Zoll, A. (1982). Okoliczności wyłączające bezprawność czynu (zagadnienia ogólne). Warszawa: Wydawnictwo Prawnicze.

Zoll, A. (2005). "Pozaustawowe" okoliczności wyłączające odpowiedzialność karną w świetle konstytucyjnej zasady podziału władzy. In Leszczyński, L. et al. (Eds.) W kręgu teorii i praktyki prawa karnego : księga poświęcona pamięci Profesora Andrzeja Wąska (425-438). Lublin: Wydawnictwo Uniwersytetu Marii Curie-Skłodowskiej.

Zoll, A. (2009) W sprawie kontratypów. Państwo i Prawo 758 (4), 108-114.

Zoll, A. (2010). Czy jest uzasadnione wyróżnianie pierwotnej i wtórnej legalności. In Choduń, A. \& Czepita, S. (Eds.) W poszukiwaniu dobra wspólnego. Księga jubileuszowa Profesora Macieja Zielińskiego (357-367). Szczecin: Wydawnictwo Naukowe Uniwersytetu Szczecińskiego.

Zontek, W. (2017). Modele wyłączania odpowiedzialności karnej. Kraków: Krakowski Instytut Prawa Karnego Fundacja.

Żółtek, S. (2014). O znamionach prawnokarnych. In Jędrzejewski, Z. et. al (Eds.) Między nauką a praktyką prawa karnego. Księga jubileuszowa Profesora Lecha Gardockiego (413-426). Warszawa: Wydawnictwo C. H. Beck. 